\title{
Interactions between forest stands and microclimate: Ecophysiological aspects and consequences for silviculture
}

\author{
Gilbert Aussenac \\ Unité d'Écophysiologie Forestière, INRA, F-54280 Champenoux, France
}

(Received 9 July 1999; accepted 1 December 1999)

\begin{abstract}
At a local scale, forest trees and stands have a marked influence on climate; thus it is possible to define microclimates. These effects depend on local climatic characteristics and stand type. All climatic parameters should be considered, but particular attention should be paid to temperature, light and water. From a silvicultural point of view knowledge of the interactions existing between microclimatic conditions and stands, in conjunction with information now available concerning tree ecophysiology make it possible to produce viable applications which are useful for silviculture during stand formation, and for applying silvicultural treatments. Whitout a doubt, taking forest cover interactions into account (climate and ecophysiological potential of species) is the basis of sustainable management in forests. Based on the current knowledge about young stands, it is possible to use existing vegetation cover, in a more or less modified form, to improve temperature conditions especially in relation to spring frost damage, and to improve water conditions for both plant uptake and plant growth for a variable period depending on the species, but for a minimum of 4 to 5 years. For clearing and thinning, the effects of microclimatic changes created by this type of forestry management, and consequently the response of trees in terms of photosynthesis and growth, are now well defined.
\end{abstract}

\section{forest stands / microclimate / ecophysiology / silviculture}

Résumé - Interactions entre peuplements forestiers et microclimat : aspect écophysiologique et conséquences pour la sylviculture. Les arbres et les peuplements forestiers exercent, au niveau local, des influences notables sur le climat ; on peut alors définir des microclimats. Ces influences sont dépendantes des caractéristiques du climat local et des types de peuplement. L'ensemble des paramètres climatiques sont à considérer, mais une attention particulière doit être portée à la température, à la lumière et à l'eau. Au plan sylvicole la connaissance des interactions existant entre conditions microclimatiques et peuplements, couplées aux informations maintenant disponibles concernant l'écophysiologie des arbres permettent de déboucher sur des applications fiables, utilisables par la sylviculture pour la création des peuplements et la mise en oeuvre des traitements sylvicoles. Incontestablement la prise en compte des interactions couvert forestier - climat et potentialités écophysiologiques des essences est à la base d'une gestion durable des forêts. Sur la base des connaissances actuelles et pour ce qui concerne les jeunes peuplements, il est possible d'utiliser le couvert végétal préexistant, plus ou moins modifié, pour améliorer les conditions thermiques notamment au plan des risques de dégâts de gel au printemps et pour améliorer les conditions hydriques tant pour ce qui concerne la reprise que la croissance des plants pendant une période variable selon les espèces, mais d'une durée minimale de 4 à 5 ans. Pour les dégagements et éclaircies l'effet des modifications microclimatiques induites par ces interventions sylvicoles et en conséquence la réaction des arbres au plan de l'activité photosynthétique et de la croissance sont maintenant bien précisés.

forêt / microclimat / écophysiologie / sylviculture

* Correspondence and reprints

Tel. 03833940 25; Fax. 03833940 69; e-mail: aussenac@nancy.inra.fr 


\section{INTRODUCTION}

The dynamic behaviour of forest trees and stands is being changed constantly by interactions between cover, biotic and abiotic conditions, and especially climatic and microclimatic conditions. In forestry, the concept of interaction between forest stand and climate is defined by:

- exchanges of energy and mass;

- changes in the nature, structure, composition and ecophysiological behaviour of cover and the different of the stand components;

- microclimatic conditions created by the physical characteristics of the cover;

- and finally for the forester the effects on survival, tree growth and stand development.

The presence of vegetation cover in general and forest cover in particular modifies the climatic parameters and creates a microclimate whose characteristics depend on the general climate itself and the physical characteristics defining the nature and structure of the cover. These phenomena have been studied from various angles by many authors, notably $[6,16,25,26,42,46,62,92,96]$. In fact, cover, i.e. the trees and vegetation in which it consists, adapts to these new microclimatic conditions by modifing its specific architectural and functional components. Thus, it is really an interactive and even a retroactive system: any change in one of the components results in an adjustment of the others, and so on (figure 1). In reality, for a forest tree it is the overall ecophysiological behaviour which is affected by these interaction phenomena, as much in terms of photosynthetic processes, transpiration, translocation, transport and storage of assimilates, as growth, flowering or fruiting phenomena.

In this paper, after a short presentation of the effect that cover has on climate, and the influence of microclimate on forest cover characteristics, we will try set out the type of information which can be obtained from understanding these interaction phenomena for use in forest management, especially in terms of stand establishment and thinning practices, by using a few examples which take forest tree ecophysiology into account.

\section{THE INFLUENCE OF FOREST COVER ON THE MICROCLIMATE}

All variables defining climate: solar radiation, air and soil temperature, rainfall, air humidity and wind, are greatly modified by forest cover which creates a microclimate. The greatest changes are brought about by adult stands with closed canopies and high leaf area indexes

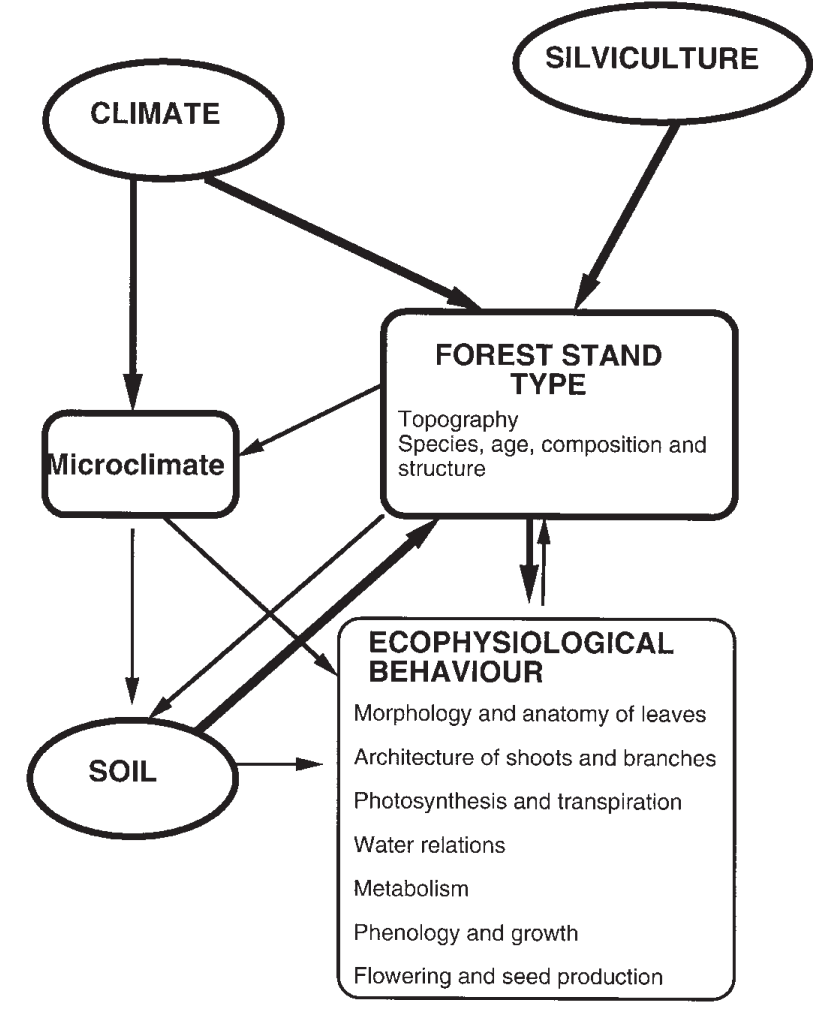

Figure 1. Interactions between climate and forest stand.

(LAI); natural modifications (windbreaks or the death of one or several trees) or artificial intervention by the forester, (clearfelling, clearing, strip felling, shelterwood, seed felling, thinning) modify the climatic characteristics to a greater or lesser extent, depending on the degree of LAI reduction and canopy opening. Various studies carried out, especially at INRA Nancy have resulted in the quantification of these influences and the definition of typical microclimatic profiles in terms of the nature and type of land use.

With reference to solar radiation, the presence of cover results partly in a reduction in the amount of radiation and partly in modifications in the spectral composition. The decrease in solar radiation depends both onf LAI and the characteristics defining the position and distribution of leaves in the cover [19, 23, 54, 82, 84]. For more open covers, figure 2 [92] shows the changes in solar radiation (as a percentage of solar radiation of open land) in clearings and in strip fellings of increasing width.

The study of light distribution in forests has been the subject of numerous works and many models have been 


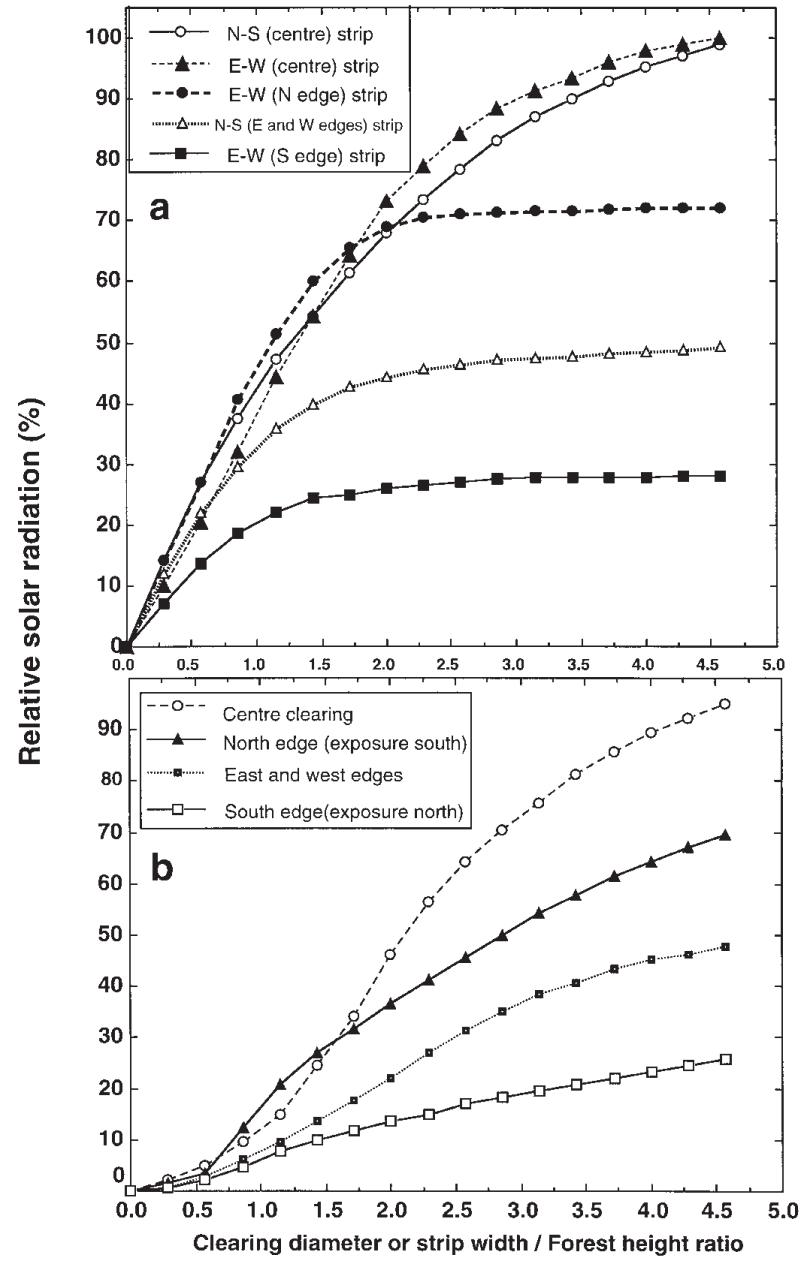

Figure 2. The increase in relative solar radiation as the size of the clearing or strip increases (Clearing ratio diameter or strip width/Forest height) (Redrawn from Roussel 1972).

formulated; in general, the decrease of solar radiation is expressed according to Beer's law. The level of solar radiation near the ground is a variable related to LAI [31, 93], crown structure [59] and canopy openess as a result of forest management. With reference to quality, light under cover is lower in (PAR) photosynthetic active radiation (blue, orange and red ranges), and this is more pronounced under broadleaved trees than coniferous trees [17]. The ratio between red radiation and long wave red may play a photomorphogenic role in growth and competition in seedlings and plants [87].
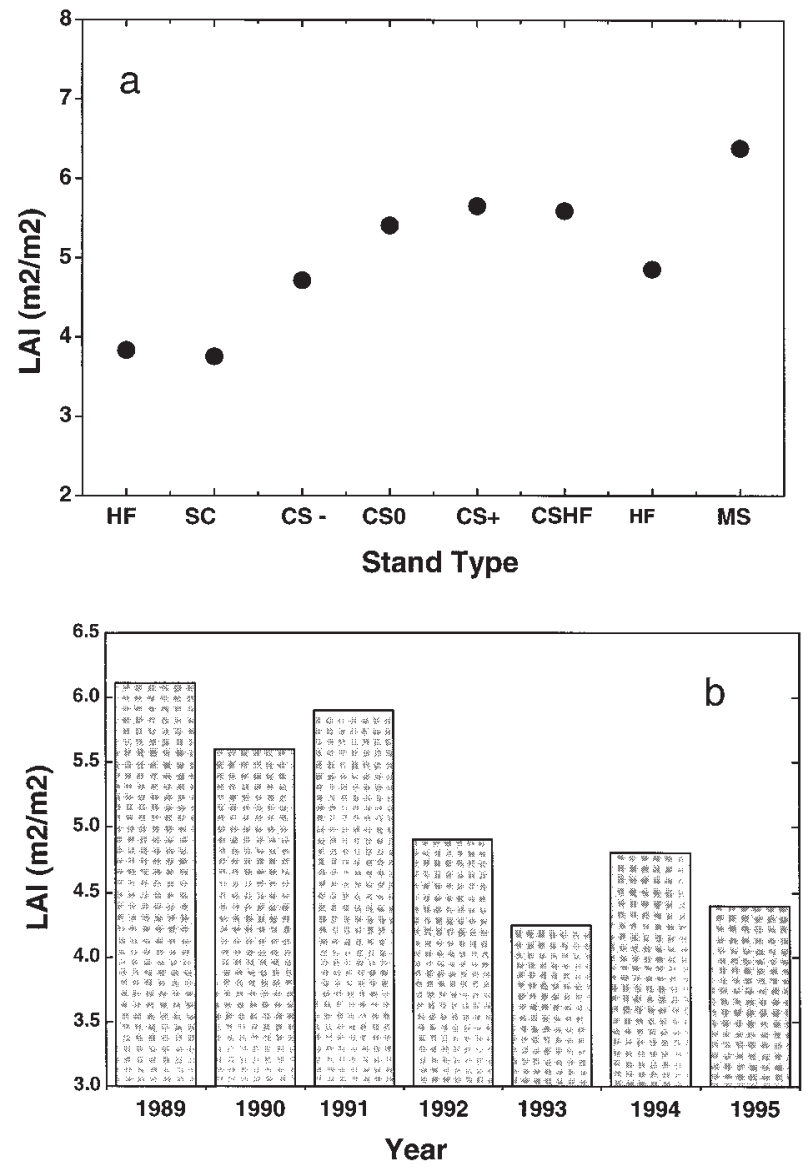

Figure 3. a) Leaf area index (LAI) against the type of forest stand, HF: High broadleaved forest, SC: Simple coppice, CS-: poor Coppice with standards, CSo: medium Coppice with standards, CS+: rich Coppice with standards, CSHF: Mixed stand with coppice under standard and high forest, MS: Mixed stand with coniferous species, b) Example of inter annual variation of Leaf area index (LAI) in an oak stand (from Bréda 1998).

Light distribution within and under the cover is highly dependent on LAI [82] which is itself depends on stand type (figure 3a) [22] and is strongly influenced by different factors, especially climatic factors and notably water availability; also, depending on the year, large differences in leaf area index can be seen (Figure 3b) [22], resulting in microclimatic variations.

In the forest, as is the case above bare soil, temperature distribution is different during the night and day, but in a forest stand the temperature profile is more complex, because the vegetation masses which absorb and emit 
radiation have variable distributions, depending on the situation. In general, forest cover buffers the daily and seasonal temperature differences compared to open ground and notably the clearfelling areas.

It can also be observed that soil temperature is affected by the nature and density of cover. In general, soils under forest cover are warmer in the winter and colder in the summer than clearfelling areas; these phenomena can be detected down to depths of 80 to $100 \mathrm{~cm}$, and temperature differences may reach 4 to $5^{\circ} \mathrm{C}[6,30,55,64]$. In fact, soil temperature is a microclimatic parameter which is often forgotten when studying the ecophysiological behaviour of forest stands. This is in spite of the fact that, depending on the species, autors demonstrated considerable if variable effects on photosynthesis, respiration, transpiration and growth. Soil temperatures below $7{ }^{\circ} \mathrm{C}$ reduce photosynthesis and transpiration, probably due to an increase in water viscosity, while a reduction in growth could be due to a reduction in the hormone supply combined with an increase in ABA production [70].

In forestry shelter phenomena should be taken into account, especially in the spring when there may be late frosts. These can be accentuated by a meteorological situation characterised by clear skies with no cloud cover, low humidity and low wind speeds. In addition, topographic conditions, i.e. depressions where dense cold air accumulates, give rise to situations where there is a higher risk of frost.

Rainfall is also strongly influenced by the nature and structure of cover, as much with regard to interception phenomena as, to its distribution on the ground $[6,11]$. Rainfall interception is considerable in stands with closed cover and may reach $30-45 \%$ of annual precipitation; the grass layer alone can intercept up to 4 to $5 \%$ [94].

Forest canopy influences and reduces wind speed in relation to the size and spatial distribution of the biomass. In fact, in certain cases, an opening in the cover may generate turbulence which can damage the surrounding trees, especially where very dense stands are concerned. The wind also acts directly or indirectly on transpiration and photosynthesis. By reducing resistance to water transfer and accelerating exchanges, it facilitates evaporation and in certain cases leaf drying inducing stomata closure which reduces photosynthesis [101].

Absolute air humidity in the forest is not very different from that observed in the open. However, relative humidity is generally higher in conjunction with the lower temperatures within the forest. In clearings, thinned stands and strips, relative humidity is intermedi- ate between clearfelling areas and stands with more closed cover.

Lastly, a composite parameter exists which characterises the hydric microclimate within and below the canopy which is highly influenced by forest cover: this is potential evapotranspiration, which defines the degree of evaporation capacity of the air at the level under consideration. It is a function of available solar radiation, temperature of the air and evaporating surfaces, air humidity and wind speed. In general, this parameter will be lower to a greater or lesser extent than in open ground, depending on the density of the cover considered: in a clearing $(H / D=0.5$ see below $)$ a $40 \%$ lover potential evapotranspiration value, has been observed compared with an open ground situation [6]. This parameter is highly important because it defines the level of water stress of atmospheric origin to which the trees are subjected. It is well known that an increase in the air water deficit has a depressing effect on stomatal opening, and therefore on the gas exchanges related to transpiration and photosynthesis [51, 52].

In general, forest stands have higher evapotranspiration rates than other types of vegetation; and any opening in the cover results in a reduction in the amount of water consumed. In relation to this phenomenom and in clearfelling areas of forest sites on hydromorphic soils, it can be observed long lasting but very near surface temporary water tables are formed which can endanger the survival of plantations or natural seedlings. In shelterwood, seed felling strip and clearing the presence of trees limits this near surface rise in the water table (figure 4). Conversely, this water table is limited in depth and therefore not partularly harmful to seedlings and plants, represents an additional water reserve which feeds the soil water reserve.

\section{MODIFICATIONS IN FOREST COVER CHARACTERISTICS RELATED TO MICROCLIMATE CONDITIONS}

As a reaction to the microclimatic conditions they have caused or which have been imposed on them by the forest manager, the architectural, anatomical, morphological and physiological components of trees are influenced and adapt to these microclimatic modifications. Depending on the parameter considered, these modifications are more or less favourable for tree development; this also depends on the state of development and on age, since a young seedling has different requirements from other trees. Below, we give some examples of adaptation and the effects of microclimatic conditions on trees. 


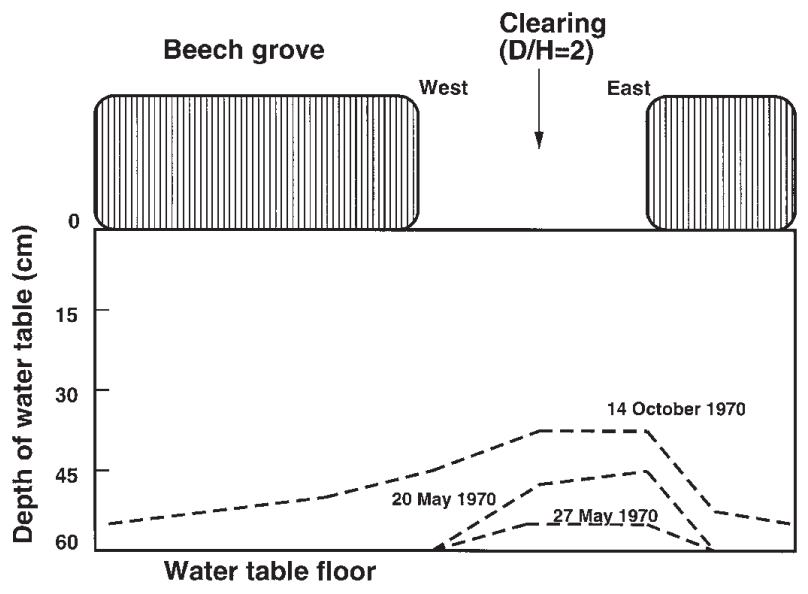

Figure 4. Local variation of water table in the soil in relation with opening canopy (from Aussenac 1975).

\subsection{Architectural adaptation}

In general, especially in young trees, it can be observed that branches adapt architecturally depending on the available light level [6]. The inclination angle of branches is greatest when they grow in the shade. An increase in light as a result of the removal of the shade layer for example, leads to a rapid modification in the architecture of the tree [7] during the following year.

At the top of the crowns, where overall radiation and radiation useful for photosynthesis reach a maximum, the leaves are erect and their inclination angle from the horizontal is very high; it declines, i.e. the leaves approach the horizontal, further wirthin the crown and as overall radiation and active photosynthetic radiation decrease. A study [50] showed that the inclination angle of leaves with respect to canopy thickness, for Fagus silvatica and Quercus petraea, follows Beer's law, and also that beech adapts better to excess and very low radiation than oak. This type of tropism can also be seen in conifers.

\subsection{Leaf adaptations}

In general, can also be observed changes, in the anatomy and size of leaves at the base of the crown, which are thinner and larger than at the top (Abies alba, Abies nordmanniana, Picea abies, Pseudotsuga menziesiis [4], Fagus sylvatica, Quercus petraea [8], Larix leptolepis [60], Abies amabilis [97, 106]. Other characteristics, such as the degree of succulence (relationship between water saturation level and fresh foliar area) show significant variations in relation to light. All these differences make it possible to define sun leaves and shade leaves with intermediate types (half shade leaves) between the two [4].

Due to their small size and very limited effect on climatic parameters, seedlings and young plants only have one type of leaf which adapts to the microclimatic conditions resulting from the influence of the existing vegetation and neighboring trees: sun leaves in clearcut areas, and shade leaves under the cover of shelterwood with a relative light level of less than 10 to $15 \%$, or intermediate leaves in clearings, strip felling or forest edges with relative light levels of between 15 and $50 \%$. In relation to growth dynamics and the size growth of trees, and thus canopy closure, crowns progressively develop sun leaves and then shade leaves which better utilise the reduced radiation. In fact there is a continuum between shade and sun leaves related to the genetic potential of each species to adapt to a reduction in light levels.

Depending on their anatomical and morphological characteristics, crown leaves have different photosynthetic activity: the shade leaves are characterised by higher photosynthesis rates than sun leaves in low light conditions, and conversely in strong light conditions. In beech depending on the stage in the vegetation season, maximum photosynthesis (as a function of dry weight) of shade leaves can be higher, lower or equal to that of sun leaves [95]. Therefore, in general the cover is "organised" in such a way as to optimise carbon fixation; when canopy homogeneity is disturbed by gaps due, for example, to clearing, some of the crown leaves will benefit from light stimulation: these are the intermediate zone leaves, half shade leaves and half sun leaves, but the shade leaves in the lower parts of the crown will not be adapted to the new microclimatic conditions created by an increase in light, both in terms of transpiration and photosynthetis and will disappear if light intensity is too high.

\section{REGENERATION AND GROWTH OF YOUNG STANDS}

Natural or artificial regeneration is an essential phase of sustainable forest management; an understanding of climate-cover interactions and their effects on ecophysiology is extremely useful to help the forester to optimise the environmental conditions (water status of the plants, temperature conditions, light) and adapt them requirements of the species or provenances. For natural regeneration, it is well known that natural (windbreak) or planed thinning of the cover by the forester (seed felling) is 
more or less beneficial for germination and the development of seedlings, depending on the size of the opening (D/H ratio), ecophysiological characteristics (shade tolerance, drought and late frost sensitivity, etc.) and the species concerned [47].

\subsection{Artificial regeneration}

With respect to artificial regeneration, the regrowth of plants after planting, especially plants with bare roots, depends on the general water conditions, notably climatic and microclimatic conditions; the regeneration and growth of new roots, which are vital for supplying water to the plants, requires about fifteen days. During this critical period, the water potential of the plants decreases even further if the water conditions, defined by local potential evapotranspiration, are unfavourable. It is known that the regrowth of plants is endangered if they reach a predawn water potential of about $-1.7 \mathrm{MPa}[12$, $44,45]$. Regrowth conditions will also be more difficult in clear felled areas than in clearings or strip fellings, all other factors being equal.

\subsection{Water supply and interactions with the light microclimate}

Controling grass and shrub layers to reduce competition for water may be necessary in very young stands and under water deficit conditions. Partial or total clearance of the grass or shrub layer reduces rainfall interception and transpiration thus reducing competition for water during water deficit conditions [89, 110]. Work has been carried out on the role of bracken in a 45 year old Pinus sylvestris stand [91] and on the influence of Gaultheria shallon Pursh in Douglas Fir stands [57]; in another work [108] transpiration in the undergrowth represented $50 \%$ of the total evapotranspiration in a Pinus radiata stand and in a maritime pine stand the importance of Molinia coerulea L. Moench transpiration (Table I) is demonstrated by others authors [69]. The results of all these works [70] clearly demonstrate and confirm the potential for the forester to improve the water supply and thus water potential in trees if necessary [78]. Improving water potential has positive effects on photosynthesis as shown in a work on Douglas Fir [87] (figure 5).

Competition phenomena related to herbaceous and semi-woody vegetation can severely limit the growth or even the survival of young trees, as shown by several autors $[27,28,41,63]$. With respect to valuable broadleaved trees, the use of mulch as in horticulture or viticulture can be highly efficient. It is also known that
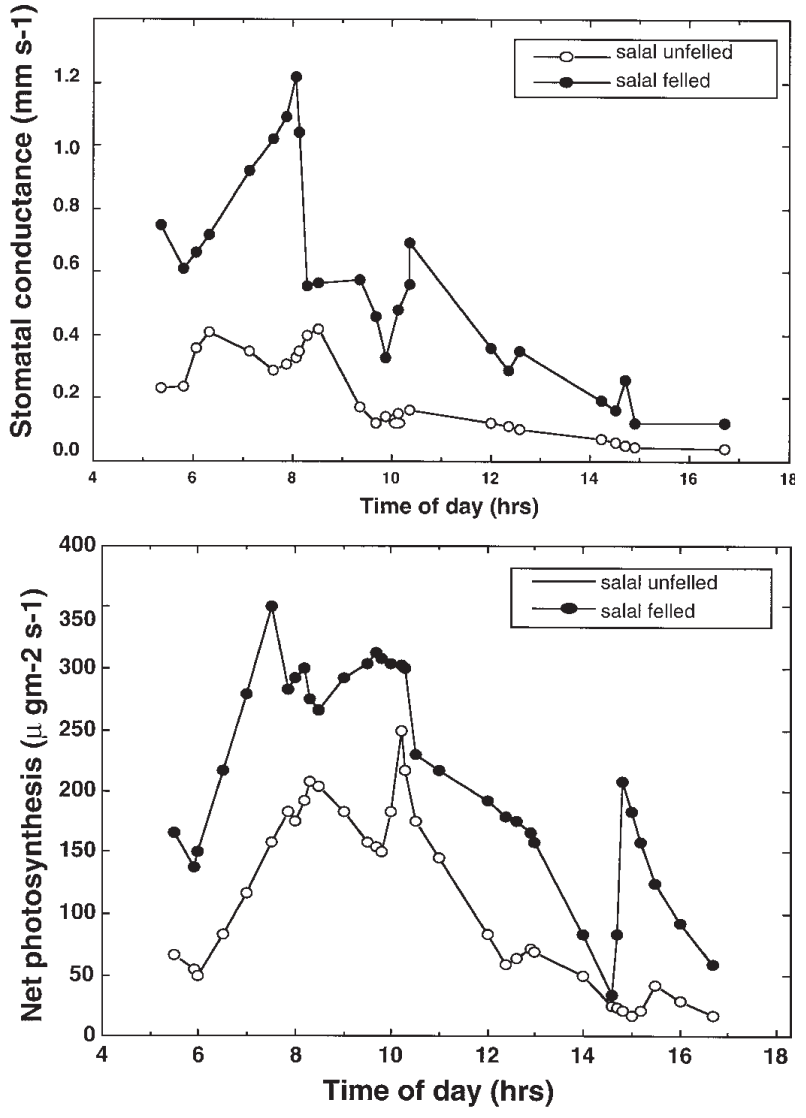

Figure 5. The effect of vegetation removal on stomatal conductance and net photosynthesis of Douglas fir (Redrawn from Price et al. 1986).

the risk of late frost damage depends on trees height, so the forester should initially encourage growth in height.

Apart from aspects related to the planting period, the use of more or less dense canopy can improve the general growth conditions of young trees. Work carried out by severals authors [63, 66, 67, 68], [9, 10, 38, 92] and [105] has shown that, in general, in humid temperate regions, young trees (except for some species such as pines, larches and aspens) have optimum growth under relative light conditions between 25 and $75 \%$ (figure 6), depending on the species and ecological conditions. These light levels correspond to the situation in clearings, strip fellings or forest edges, figure 7 [9] shows the cumulative heights observed in shelterwood and clearing in comparison with clear fellings, for 9 year old plants of European Silver Fir, Caucasian Fir, Norway Spruce and Douglas Fir. In this example higher growth 


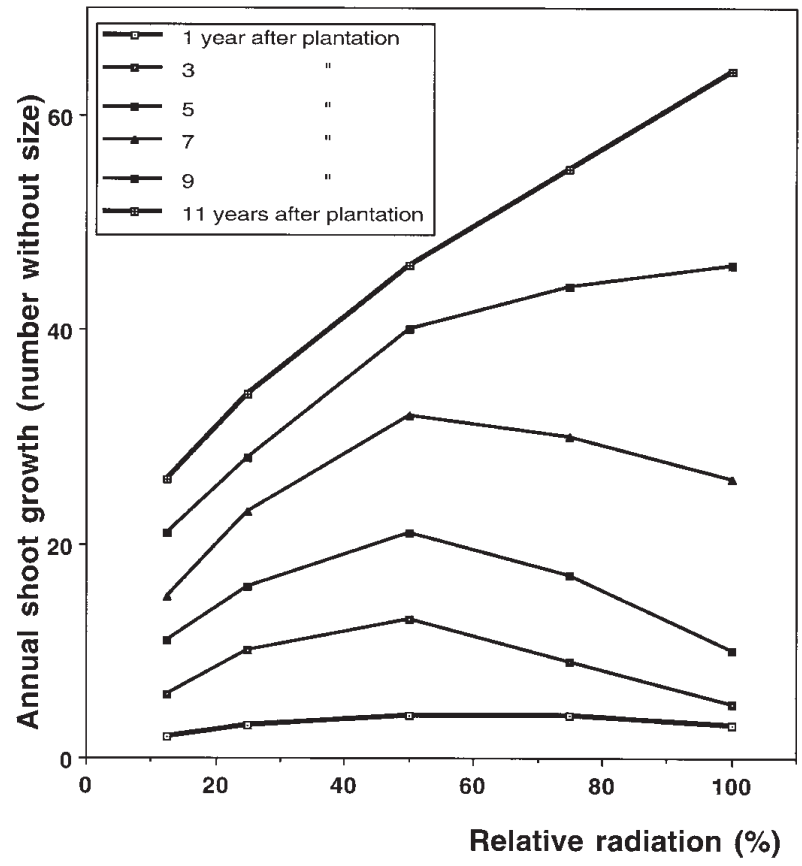

Figure 6. Annual shoot growth against solar radiation, evolution with tree age (from Aussenac and Ducrey 1978).

was observed in the clearings than in the other treatments. Diameter growth (figure 7) depended on the species considered, and was highest in the clearings (Abies alba and Abies nordmanniana) or clearcut areas (Picea abies and Pseudotsuga menziesii). At first sight, improved growth under lower light conditions than in the open could be interpreted as being entirely due to the influence of moderate lighting. In fact, it is the overall
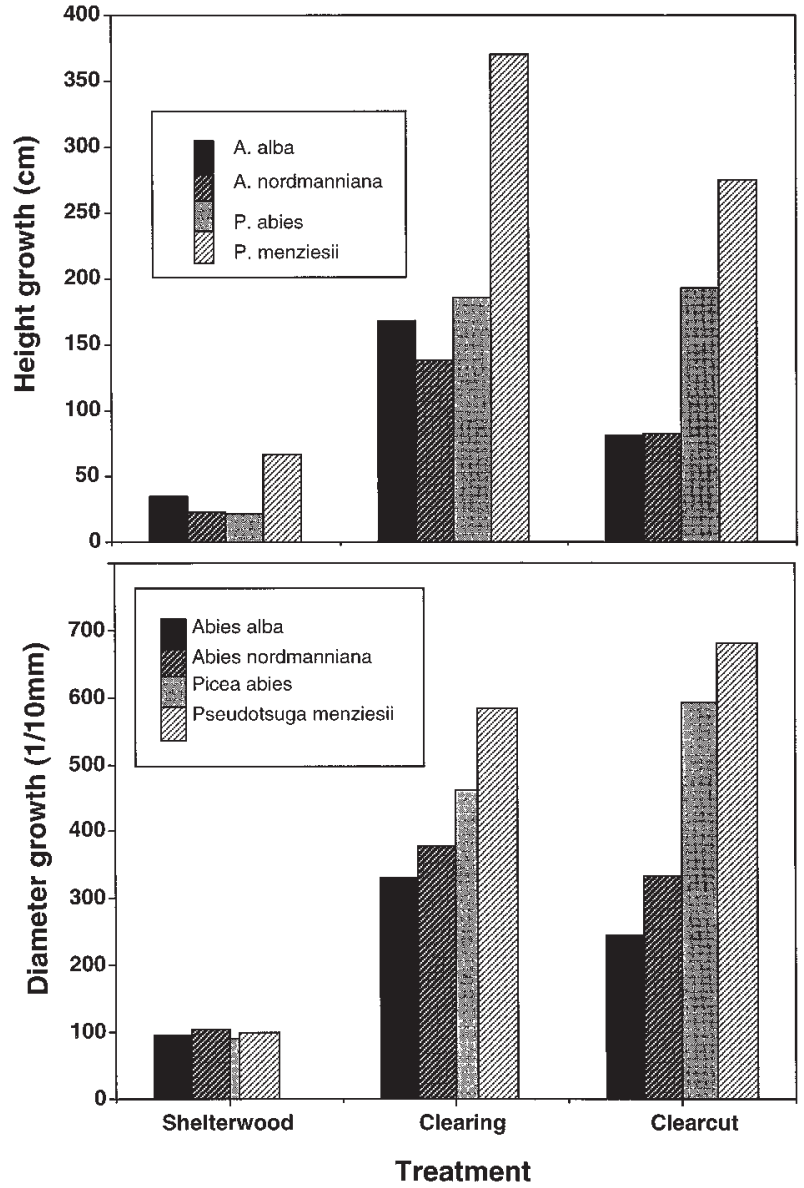

Figure 7. Effect of microclimatic conditions on height and diameter increments of several conifers (from Aussenac 1977).

Table I. Evapotranspiration of understorey and transpiration of trees in a Pinus pinaster forest stand during a dry summer (1989) (from Loustau and Cochard 1991).

\begin{tabular}{|c|c|c|c|c|c|}
\hline Date & 13 June & 2 July & 21 July & 6 September & 28 September \\
\hline $\begin{array}{l}\text { Evapotranspiration }(\mathrm{Ev}) \\
\text { From the understorey }(\mathrm{mm} / \text { day })\end{array}$ & 1.09 & 1.09 & 0.89 & 0.63 & 0.36 \\
\hline $\begin{array}{l}\text { Transpiration from pines }(\mathrm{T}) \\
(\mathrm{mm} / \text { day })\end{array}$ & 2.10 & 1.21 & 0.45 & 0.19 & 1.20 \\
\hline PTE (mm/day) & 3.20 & 3.54 & 6.20 & 5.14 & 1.93 \\
\hline Ev/PTE & 0.34 & 0.31 & 0.14 & 0.12 & 0.19 \\
\hline $\mathrm{Ev} / \mathrm{T}$ & 0.51 & 0.90 & 1.97 & 3.31 & 0.30 \\
\hline
\end{tabular}


water conditions which are improved; in shaded areas, low light levels correspond to a reduction in local evapotranspiration potential: light, temperature and wind are reduced, compared to open land. This reduction in potential evapotranspiration improves the water status of the plants (higher predawn water potential and minimum water potential) $[32,72]$ and thus improves photosynthetic activity and growth, as shown by experiments in forest but under controlled conditions [9].

In fact, after the establishment phase and juvenile growth which lasts from 5 to 10 years depending on the species and the ecological conditions enabling an adequate rooting system to develop trees require maximum light conditions which should be provided by the forester by clearing the cover. Certain species, such as Abies alba require shade for longer periods of time than other species such as Picea abies. As a general rule, the more favourable the water conditions in the site, the shorter the period of shade will be.

\subsection{Temperature interaction phenomena related to late frosts}

The temperature interaction phenomena described in the previous section, related to the amount and structure of cover, become particulary important during late frost situations. It is well known that the risk of damage by late frosts is higher in humid temperates and even Mediterranean climates, particulary in Western Europe and France than in other climates. The risk of damage varies depending on the species [98]. It is also known that, for certain species such as the European silver fir, increasing the lateness of bud break by genetic modification is not possible, due to the very low variability of this characteristic. Thus the use of forest or low vegetation cover may be an efficient solution for protecting certain species such as European silver Fir and Douglas fir with early bud break from frost damage [5].

Table II compares the temperatures and damage observed during a late frost in Lorraine (France) with those of a clearcut area [6]. It shows the role of late bud break in some species and the beneficial effect of cover, whether vertical in the shelterwood or lateral in the clearing. In fact, in the latter treatment the effect depended on cover size relative to the height of the surrounding stand (Diameter/height ratio) [42]. Above a $\mathrm{D} / \mathrm{H}$ ratio of 3 , the protective effect disappears. Furthermore, it can be observed that the net radiation balance in the centre of a clearing becomes negative for a $D / H$ ratio of over 2 [62].

In a shelterwood or seed cutting for regeneration, cover should be considerable (relative light less than or equal to $50 \%$ ) to reduce the effect of late frosts. Strip
Table II. Influences of forest opening on night time minimum temperature $\left({ }^{\circ} \mathrm{C}\right)(04 / 05 / 1967)$ in Lorraine near Nancy, and frost damage (\% of total trees), Abies alba (1), Abies nordmanianna (2), Picea abies (3) and Pseudotsuga menziesii (4) saplings (from Aussenac 1967).

\begin{tabular}{cccc}
\hline & Clearcut & \multicolumn{2}{c}{ Shelterwood Opening $(D / H=2)$} \\
\hline & & \multicolumn{2}{c}{ air temperature $\left({ }^{\circ} \mathrm{C}\right)$} \\
& -2.5 & 1.0 & 0.5 \\
$(1)$ & & frost damage $(\%$ trees $)$ \\
$(2)$ & 86 & 0 & 17 \\
$(3)$ & 6 & 0 & 0 \\
$(4)$ & 0 & 0 & 0 \\
& 8 & 0 & 0 \\
\hline
\end{tabular}

felling gives limited protection against late frosts if the width is over twice the height of the surrounding stand, and if the wooded bands in between are narrow. When they are perpendicular to the dominant winds they may accentuate the risk of damage near the intermediate bands, due to the reduction in wind speed [3]. The efficiency of shelter depends both on the characteristics of the existing cover and the climatic conditions. In Canada, [48] it can be observed that for a $\mathrm{D} / \mathrm{H}$ ratio of over 0.95 , frost damage affected $50 \%$ of Picea glauca planted in strips and clearings, compared with $2 \%$ under cover and in clearings with a $D / H$ ratio $=0.47$.

For shelterwood, the cover should be removed in the winter to allow development of new leaves, which are more adapted than existing shade leaves as well as for transpiration as photosynthesis. Rather than large clearcut areas, the opening of clearings with a more favourable microclimate is recommended. Under these conditions, the trees recently exposed to light do not undergo a shock effect after clearing and exhibit an increase in diameter growth as of the first year. The increase in height growth only occurs as of the second year, as shown in a work [6] on Douglas fir, Norway spruce, European silver fir, and Caucasian fir (figure 8). These results show that the cambial function is greatly affected by the climatic and microclimatic conditions of the current year, whereas the apical meristem function also depends on the conditions of the current year, but above all on those of the previous year.

It should be remembered that topography can be an exacerbating factor with regard to late frosts, as it favours the accumulation of cold dense air, especially in valley bottoms [37, 76, 79]. Therefore, when preparing plots for re-afforestation, one should try to avoid hollows and swaths as far as possible as they down or stop air flow. 

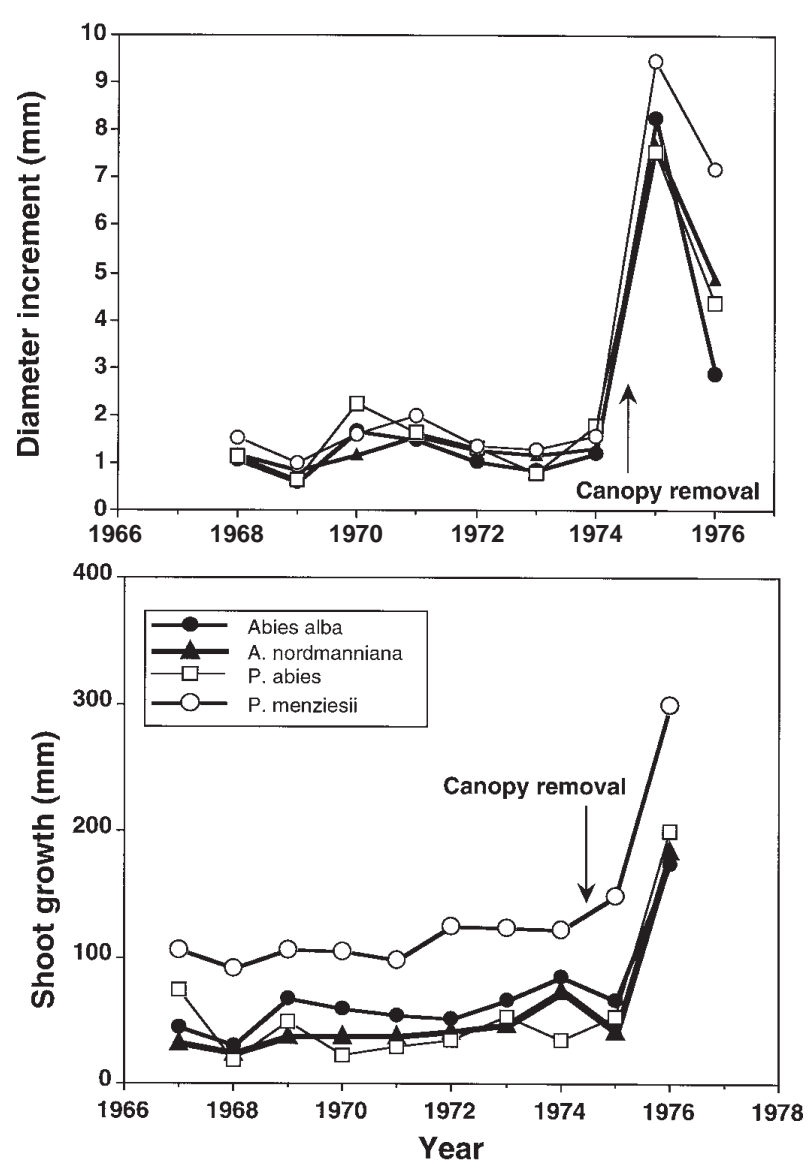

Figure 8. Influence of canopy removal on diameter increment and shoot growth of several conifers (from Aussenac 1977).

Microclimatic analysis and the ecophysiological responses of different forest species show the importance of using the shade from existing cover (clearing, strip felling, shelterwood) when planting new stands and for periods of between 5 and 10 years depending on the species and ecological conditions. Thus, when establishing a plantation or seeding a clearcut area, depending on the circumstances, one should let the plant develop in competition with the surrrounding vegetation which provide a useful shelter against late frosts. This shelter should be removed as soon as the trees begin to emerge from the vegetation layer so as to avoid late frost damage and benefit from higher water availability. For valuable species, one should also envisage the use of mechanical or chemical hoeing or even mulching to increase growth.

\section{THINNING}

Thinning is an essential operation in silviculture. Depending on the type and intensity, it results in greater or lesser changes in the environment of the remaining trees. Thinning is usually defined in terms of stand density at a given age, but now progress in forest ecophysisiology means that thinning problems can be resolved on a functional basis, taking into account the physiological behaviour of the trees and physical environmental constraints (light, temperature, water, wind). Removing some trees from a stand results in changes in the microclimate which lead to major changes in the ecophysiological behaviour of the trees: with respect to photosynthesis and transpiration phenomena [1], but also to growth, form and size of the remaining crowns.

\subsection{Improvement in soil water availability}

Apart from an increase in light intensity, the direct effect of which is increased photosynthesis [56, 101], thinning also produces a marked improvement in soil water availability $[29,33,74,99,100,104]$. This reduces the intensity and duration of summer water stress as shown by table III [13] for a 19 year old Douglas fir stand, and figure 9 for an oak stand [20, 21]. Improvement of soil water availability, linked to a reduction in transpiration ( $21 \%$ lower), has also been reported by [75] in a Chamaecyparis obtusa stand after thinning which removed $25 \%$ of the trees. An improvement in the water supply, linked to a reduction in the interception of precipitation and transpiration, disappears more or less rapidly, depending on the speed at which the area is recolonised, whether aerial or underground, by the trees of the thinned stand (figure 10). It should be added that [2], for the soil water level to improve, thinning must be intense. Otherwise the slight increase in soil humidity will be consumed very quickly without any measurable effect on the trees.

Reduction in summer water stress has a very positive effect on stomatal conductance and photosynthetic

Table III. Number of days during whitch the predawn water potential was lower than $-0.5 \mathrm{MPa}$ (a) and $-1.0 \mathrm{MPa}$ (b) in two stands, control and thinning (1980), of Pseudotsuga menziesii (from Aussenac and Granier 1988).

\begin{tabular}{lcccccccccc}
\hline & \multicolumn{1}{c}{1980} & \multicolumn{1}{c}{1981} & \multicolumn{2}{c}{1982} & \multicolumn{2}{c}{1983} & \multicolumn{2}{c}{1984} \\
& $\mathrm{~A}$ & $\mathrm{~b}$ & $\mathrm{a}$ & $\mathrm{b}$ & $\mathrm{a}$ & $\mathrm{b}$ & $\mathrm{a}$ & $\mathrm{b}$ & $\mathrm{a}$ & $\mathrm{b}$ \\
\hline Control & 0 & 0 & 32 & 20 & 79 & 37 & 54 & 31 & 41 & 15 \\
Thinned & 0 & 0 & 0 & 0 & 23 & 0 & 40 & 22 & 39 & 8 \\
\hline
\end{tabular}




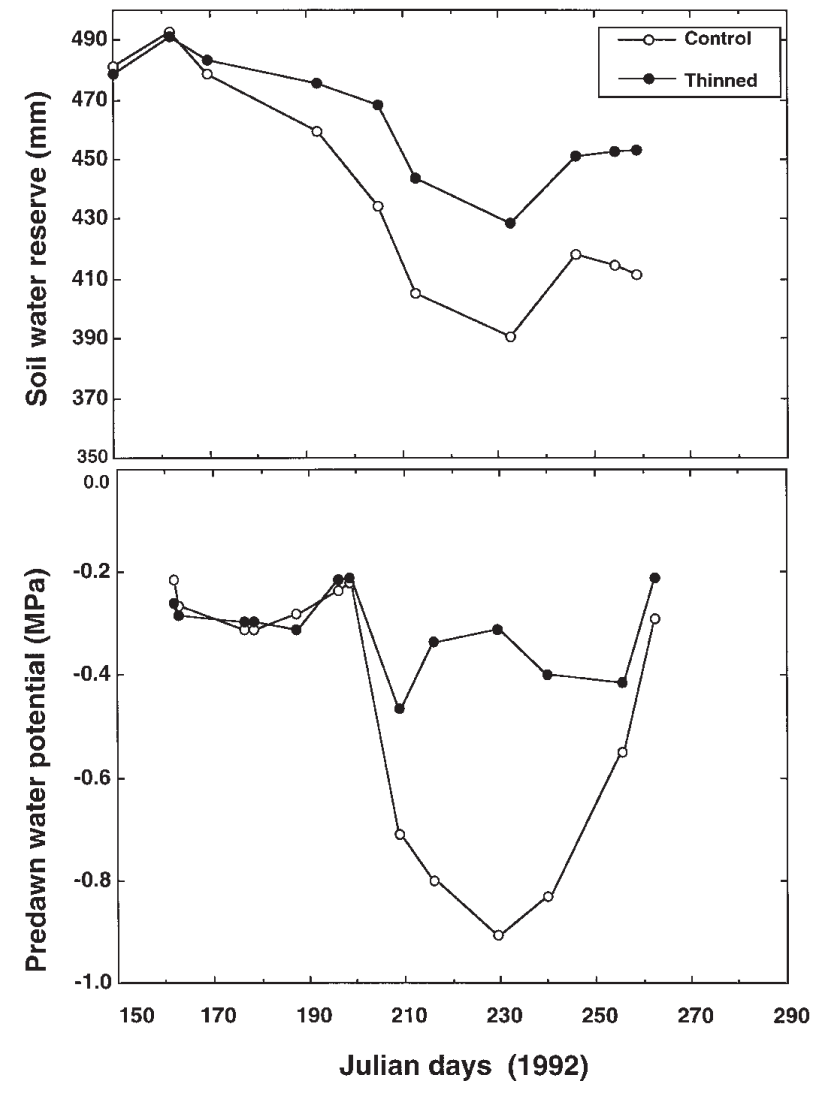

Figure 9. Influence of thinning on evolution of soil water reserve and predawn water potential in two oaks stands (from Bréda et al. 1995).

capacity [21]. In a 49 year old Pinus contorta stand, a work [35] showed a difference of $0.3 \mathrm{MPa}$ above the minimum predawn water potential which gave rise to a $21 \%$ higher in net photosynthesis of the thinned stand compared to the control.

\subsection{Influence on tree growth}

An increase in photosynthetic activity generally results in an increase in the rate of tree circumference growth as shown by severals authors who observed an increase of: 51\% for Pinus taedea [43], 50\% for Douglas fir $[11,13]$ and $34 \%$ for sessile oak [21]. This phenomenon of maintaining stand productivity after thinning has been verified for beech [34] and shade species but seems to be less of a rule for the sun species, which is probably related to the differences in LAI and the capacity of these species to intercept light. It must be remembered

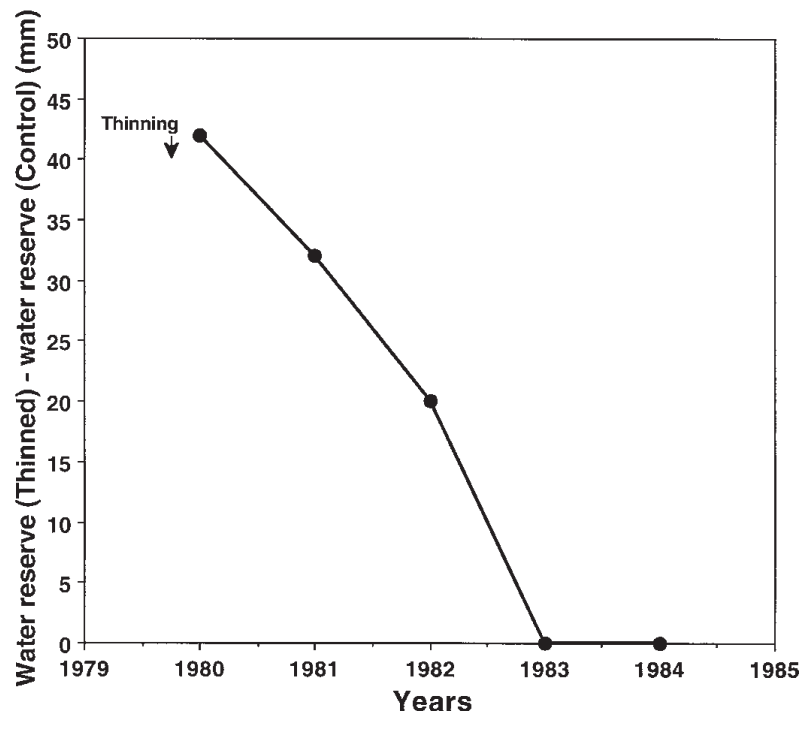

Figure 10. Evolution of difference in minimal water reserve reached during a period of maximal drought between a control and a thinned Douglas fir stand (from Aussenac and Granier 1988).

that, in a stand, shade species tend to intercept all the radiation, to the detriment of the undergrowth.

An increase in circumference growth is the result of several phenomena:

- firstly, the increase in light in the lower parts of the crown which favours photosynthesis throughout the crown $[43,85,102]$. It is also well known that photosynthesis in closed cover [109] is at a maximum in the narrow zone situated between the leaves in full light and those in the shade. Thinning also results in a significant increase in the foliar mass of the remaining trees. Thus, in a 19 year old Douglas fir stand, a $15 \%$ increase was reported linked to reduced needle fall from the base of the crowns with improved light [13], thus showing an improved carbon budget; these needles contributed to the increase in total photosynthesis evaluated for the tree;

- then, a reduction in duration and intensity of water stress which influences photosynthesis but also directly effects growth; it is known that circumference growth stops when predawn water potential is about $-0.4 \mathrm{MPa}$, while height growth is possible with a predawn water potential of -1.0 to $-2.0 \mathrm{MPa}$, depending on the species [15] (figure 11);

- furthermore, improved light under the cover and an increase in the temperature of the soil surface, result 


\section{Shoot growth (maximun \%)}

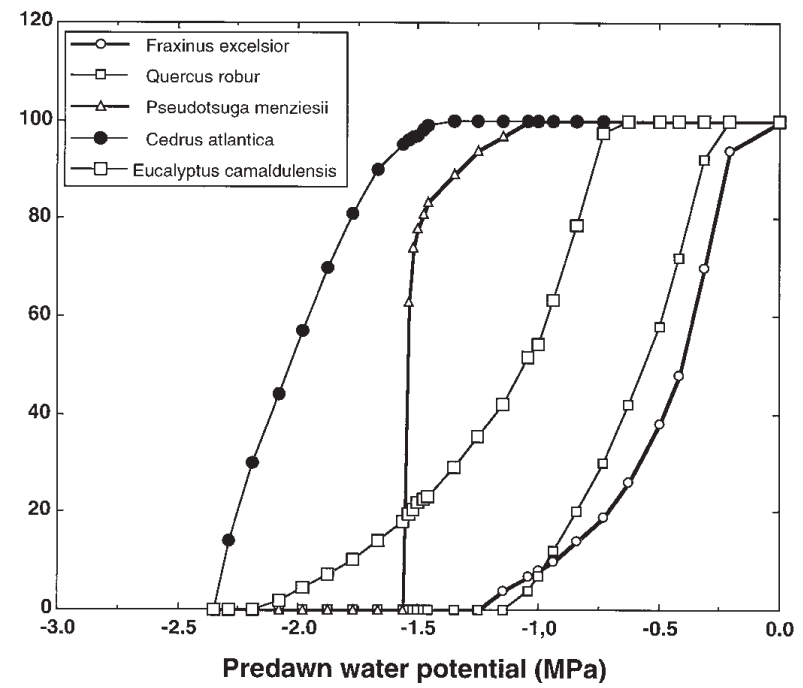

Figure 11. The effect of increasing plant water stress on shoot growth of several forest trees.

in faster humus mineralization [81, 86], which releases nitrogen compounds, a phenomenon comparable to fertilisation.

Depending on the ecological conditions and the species considered, one or more of these phenomena will have a determining influence on growth.

With respect to height growth, various authors [36, $43,53]$ have reported that thinning has a negative effect which is greater for heavy thinning than for light thinning, and may last for 3 to 4 years. This depressing effect may be due to the redistribution of assimilate towards the lateral branches, roots and the trunk; for the latter component, it must be remembered that slight water stress (see above) results in a reduction in circumference growth, probably to the benefit of apical growth which is inhibited only at much lower water potentials.

This phenomenon may also explain why an improvement in the water status of trees in thinned stands means that circumference growth is less limited, to the detriment of height growth, compared with stands of denser cover. It is also known that in stands, situations exist where for the same dominant height and all other factors being equal, trees may have lower circumference growth rates. The effects of temperature stress or photoinhibition phenomena may also occur in the case of a stand which is initially very dense and then heavily thinned.
With respect to thinning and the greater or the lesser degree of canopy opening, the problems of stand stability and risks to certain species, especially conifers on hydromorphic soils, should also be mentioned. Work carried out by several authors [77] show that:

- stand instability increases with crown development and tree height;

- with the same dominant height, unthinned stands are more stable than thinned stands, especially in the case of systematic thinning. A criterium for critical dominant height has been defined for certain species, notably Sitka spruce. One or two years after thinning the risks of windbreak are greater in the case of heavy thinning and a higher initial stand density;

- very early thinning results in progressive crown and rooting system development, at an age when the trees are not particularly vulnerable, and improves stand stability.

For silviculture, all these results, especially the improvement in water availability, humus mineralization and stability problems, recommend the use of early, heavy thinning, while controlling the development of the surrounding vegetation.

\section{CONCLUSION}

Forest trees and stands have a marked influence on climate; thus, it is possible to define microclimates. These effects depend on local climatic characteristics and stand type. All the climatic parameters should be considered, but particular attention should be paid to temperature, light and water.

From a silvicultural point of view, knowledge of the interactions existing between microclimatic conditions and stands, in conjunction with information now available concerning tree ecophysiology make it possible to produce viable applications which are useful for silviculture during stand formation, and for applying silvicultural treatments. Without a doubt, taking forest cover interactions into account (climate and ecophysiological potential of species) is the basis of sustainable and optimised management in forests. Whith respect to research, much progress has to be made, firstly in terms of improving the definition of microclimates especially in climatic zones characterised by large water deficits such as the Mediterranean climate; and secondly, in terms of improving understanding of the ecophysiology of forest species, especially their response to light and water deficits under natural conditions.

Based on the current knowledge about young stands, it is possible to use existing vegetation cover, in a more 
or less modified form, to improve temperature conditions especially in relation to spring frost damage, and to improve water conditions for both plant uptake and plant growth for a variable period depending on the species and stand density, but for a minimum of 4 to 5 years.

For clearing and thinning, the effects of microclimatic changes created by this type of forestry management, and consequently the response of trees in terms of photosynthesis and growth, are now well defined.

Furthermore, with reference to possible climatic changes, likely a plausible increase in water deficit in certain regions, it seems necessary to better adapt stands and forest management. In particular, with respect to the behaviour of adult stands, limitating the leaf area index [22] of the overstorey, as well as controling the amount of undergrowth, could be efficient ways of adjusting the water availability and water requirements of trees.

Acknowledgement: The author express his greatest thanks to Christine Aussenac for her excellent help.

\section{REFERENCES}

[1] Alsheimer M., Kostner B., Falge E., Tenhunen J.D., Temporal and spatial variation in transpiration of Norway spruce stands within a forested catchment of the Fichtelgebirge, Germany, Ann. Sci. For. 55 (1998) 103-123.

[2] Anderson H.V., Hoover M.D., Reinhart K.G., Forests and water: effects of forest management on floods, sedimentation and water supply, USDA For. Serv. Gen. Tech. Report PSW (1976) 18.

[3] Aussenac G., Étude microclimatique de coupes par bandes en forêt d'Épinal (Vosges), Comparaison avec la coupe rase, Rev. For. Fr. XXV 4 (1973) 283-293.

[4] Aussenac G., Effets de conditions microclimatiques différentes sur la morphologie et la structure anatomique des aiguilles de quelques résineux, Ann. Sci. For. 30 (4) (1973) 375-392.

[5] Aussenac G., Étude des gelées tardives en relation avec les problèmes de reboisement, Ann. Sci. For. 30 (2) (1973) 141-155.

[6] Aussenac G., Couverts forestiers et facteurs du climat : leurs interactions, conséquences écophysiologiques chez quelques résineux, Thèse de Doctorat ès Sciences, Nancy (1975) p. 234.

[7] Aussenac G., À propos de la crise de découvert des résineux, Analyse d'un cas en Lorraine, Rev. For. Fr. XXIX, 2 (1977) $127-130$.

[8] Aussenac G., Ducrey M., Étude bioclimatique d'une futaie feuillue (Fagus silvatica L. et Quercus sessiliflora Salisb.) de l'Est de la France. I. Analyse des profils microclimatiques et des caractéristiques anatomiques et morphologiques de l'appareil foliaire, Ann. Sci. For. 34 (4) (1977) 265-284.
[9] Aussenac G., Influence du couvert forestier sur la croissance de quelques résineux dans le jeune âge, Can. J. For. Res. 7 (1) (1977) 8-18.

[10] Aussenac G., Ducrey M., Étude de la croissance de quelques espèces forestières cultivées à différents niveaux d'éclairement et d'alimentation hydrique, $103^{\text {e }}$ Congrés des Sociétés savantes Nancy I (1978) 105-117.

[11] Aussenac G., Granier A., Naud R., Influence d'une éclaircie sur la croissance et le bilan hydrique d'un jeune peuplement de Douglas (Pseudotsuga menziesii (Mirb) Franco), Can. J. For. Res. 12, 1 (1982) 222-231.

[12] Aussenac G., El Nour M., Évolution du potentiel hydrique et du système racinaire de jeunes plants de Cèdre, Pin laricio de Corse et Pin noir plantés à l'automne et au printemps, Ann. Sci. For. 43 (1) (1986) 1-14.

[13] Aussenac G., Granier A. Effects of thinning on water stress and growth in douglas fir, Can. J. For. Res. 1, 18 (1988) 100-105.

[14] Aussenac G., Guehl J.-M., Granier A., Kaushal P., Grieu P., Critères physiologiques pour l'évaluation de la qualité des plants forestiers avant plantation, Rev. For. Fr., ${ }^{\circ}{ }^{\circ}$ spécial (1987) 131-139.

[15] Aussenac G., Guehl J.-M., Dépérissements et accidents climatiques, Rev. For. Fra. XLVI 5 (1995) 458-470.

[16] Aussenac G., Granier A., Breda N., Effets des modifications de la structure du couvert forestier sur le bilan hydrique, l'état hydrique des arbres et la croissance, Rev. For. Fra. XLVII 1 (1995) 54-62.

[17] Brasseur F., de Sloover J.R., L'extinction du rayonnement dans les gammes spectrales bleu, rouge et rouge lointain. Comparaison de deux peuplements forestiers de haute Ardenne, Bull. Soc. Roy. Bot. Belge. 109 (1976) 319-334.

[18] Bellefleur P., Laroque G., Compétition pour le rayonnement solaire en début de succession secondaire dans une érablière à bouleau jaune et hêtre, Can. J. For. Res. 13, 3 (1983) 514-521.

[19] Berbigier P., Bonnefond J.M., Measurement and modelling of radiation transmission within a stand of maritime pine (Pinus pinaster Ait), Ann. Sci. For. 52 (1995) 23-42.

[20] Breda N., Granier A., Intra and interannual variations of transpiration, leaf area index and radial growth of a sessile oak stand (Quercus petraea), Ann. Sci. For. 53 (1996) 521536.

[21] Breda N., Granier A., Aussenac G., Effects of thinning on soil water balance and tree water relations, transpiration and growth in oak forest (Quercus petraea (Matt) Liebl.), Tree Physiol. 15 (1995) 295-306.

[22] Bréda N., L'indice foliaire des couverts forestiers : mesure, variabilité et rôle fonctionnel, Rev. For. Fr. LI. 2 (1999) 135-150.

[23] Cannell M.G.R., Grace J., Competition for light: detections forestiers : mesure, variabilité et rôle fonctionnel Rev. For. Fr. (in press), measurement, and quantification, Can. J. For. Res. 23 (1993) 1973-1979. 
[24] Carlson D.W., Groot A., Microclimate of a clear cut, forest interior, and small opening in trembling aspen forest, Agri. For. Meteorol. 87 (1997) 313-329.

[25] Chen J., Franklin J.F., Spies T.A., Contrasting microclimates among clearcut, edge, and interior of old-growth Douglas-fir forest, Agri. For. Meteorol. 63 (1993) 219-237.

[26] Chen J., Franklin J.F., Growing season microclimate variability within an old-growth Douglas-fir forest, Clim. Res 8 (1997) 21-34

[27] Collet C., Guehl J.M., Frochot H., Ferhi A., Effects of two forest grasses differing in their growth dynamics on the water relations and the growth of Quercus petraea seedlings, Can. J. Bot. 74 (1996) 1562-1571.

[28] Collet C., Frochot H., Effects of interspecific competition on periodic shoot elongation in oak seeedlings, Can. J. For. Res. 26 (1996) 1934-1942

[29] Cregg B., Hennessey T.C., Dougherty P.M., Water relations of Loblolly Pine trees in southeastern Oklahoma following precommercial thinning, Can. J. For. Res. 20, 9 (1990) 1501-1513.

[30] Cuif, 1909, Influence du couvert de la forêt sur la température du sol à diverses profondeurs, Bulletin des séances de la Société des Sciences de Nancy, pp. 1-19.

[31] Cutini A., The influence of drought and thinning on leaf area index estimates from canopy transmittance method, Ann. Sci. For. 53 (1996) 595-603.

[32] Dalton C.T., Messina M.G., Water relations and growth of loblolly pine seedlings planted under a shelterwood and in a clear cut, Tree physiol. 15 (1995) 19-26.

[33] De Vries M.L., Wilde S.A., Effect of the density of red pine stands on moisture supply in sandy soils, Neth. J. Agri. Sci. 10, 3 (1962) 235-239.

[34] Dhote J.F., 1998, Modélisation de la dynamique des peuplements de grands feuillus sociaux. Habilitation à diriger des recherches. Université Henri Poincaré Nancy, p. 101.

[35] Donner B.L., Running S.W., Water stress response after thinning Pinus contorta in Montana, For. Sci. 32 (1986) 614-625.

[36] Ducrey M., Huc R., Effets de l'éclaircie sur la croissance et le fonctionnement écophysiologique d'un taillis de chêne vert, RFF (1999) (in press).

[37] Duffy P.J.B., Fraser J.W., Local frost occurences in eastern Ontario woodlands, Department of Forestry Publications $\mathrm{N}^{\circ} 1029$ (1963) p. 24.

[38] Fairbairn W.A., Neustein S.A., Study of response of certains coniferous species to light intensity, Forestry 43 (1970) $57-71$

[39] Frochot H., Levy G., Facteurs du milieu et optimisation de la croissance initiale en plantations de feuillus, R.F.F. XXXVIII 3 (1986) 301-306.

[40] Frochot H., Levy G., Lefèvre Y., Werhlen L., Amélioration du démarrage des plantations de feuillus précieux ; cas du frêne en station à bonne réserve en eau, R.F.F. XLIV, Nº spécial (1992) 61-65.
[41] Frochot H., Levy G., Facteurs limitants la croissance initiale d'une plantation de merisier (Prunus avium L.) sur rendzine brunifiée, Ann. Sci. For. 37, 3 (1980) 239-248.

[42] Geiger R., The climate near the ground. Harvard, University Press Cambridge (1965) p. 611.

[43] Ginn S.E., Seiler J.R., Cazell B.H., Kyreh R.E., Physiological and growth responses of eight year old Loblolly pine stands to thinning, For. Sci. 37, 4 (1991) 1030-1040.

[44] Girard S., Clement A., Cochard H., Boulet-Gercourt B., Guehl J.M., Effects of dessication on post-planting stress in bare-root Corsican pine seedlings, Tree Physiol. 17(7) (1997) 429-435.

[45] Girard S., Clément A., Boulet-Gercourt B, Guehl J.M., Effects of exposure to air on planting stress in red oak seedlings, Ann. Sci. For. 54 (1997) 395-401.

[46] Granberg H.B., Ottosson-Lofvenius M., Odin H., Radiative and aerodynamic effects of an open pine shelterwood on calm, clear nights, Agri. For. Meteorol. 63 (1993) 171-188.

[47] Gray A.N., Spies T.A., Gap size, within gap position and canopy structure effects on conifer seedling establishment, J. Ecol. 84 (1996) 635-645.

[48] Groot A., Carlson D.W., Influence of shelter on night temperatures, frost damage, and bud break of white spruce seedlings, Can. J. For. Res. 26, 9 (1996) 1531-1538.

[49] Gross K., Homlicher A., Weinreich A., Wagner E., Effect of shade on stomatal conductance, net photosynthesis, photochemical efficiency and growth of oak saplings, Ann. Sci. For. 53 (1996) 279-290.

[50] Grulois J., Extinction du rayonnement global, tropismes et paramètres foliaires. Bull. Soc. Roy. Bot. Belgique 100 (1967) 315-334.

[51] Guehl J.M., Aussenac G., Gas exchange response to air humidity in Abies alba, Plant Physiology 83 (1987) 316-322.

[52] Guehl J.M., Aussenac G., Bouachrine J., Zimmerman R., Pennes J.M. Ferhi A., Grieu P., Sensitivity of leaf gas exchange to atmospheric and soil drought and water-use efficiency in some mediterranean Abies species, Can. J. For. Res 21 (1991) 1507-1515.

[53] Harrington C.A., Reukema D.L., Initial shock and long term stand development following thinning in a douglas fir plantation, For. Sci. 29, 1 (1983) 33-46.

[54] Hassika P., Berbigier P., Bonnefons J.M., Measurement and modelling of the phothosynthethically active radiation transmitted in a canopy of maritime pine, Ann. Sci. For. 54 (1997) 715-730.

[55] Hawke M.F., Wedderburn M.E., Microclimate changes under Pinus radiata agroforestry regimes in New Zealand, Agri. For. Meteorol 71 (1994) 133-1455.

[56] Helms J.A., Apparent photosynthesis of Douglas - fir in relation to silvicultural treatments, For. Sci. 10 (1964) 432442.

[57] Kelliher F.M., Black T.A., Price D.T., Estimating the effects of understory removal from a Douglas Fir Forest using a two-layer canopy evapotranspiration model, Water Resour. Res. 22 (1986) 1891-1899. 
[58] Kelliher F.M., Whitehead D., McNeney K.J., Judd M.J., Partitioning evapotranspiration into tree and understory components in two young Pinus radiata D. Don. stands, Agri. For. Meteorol. 50 (1990) 211-227.

[59] Kellomaki S., Oker-Blom P., Canopy structure and light climate in a young scots pine stand, Silva Fenn. 17 (1983) $1-17$.

[60] Kurachi N., Hagihara A., Hozumi K., Canopy photosynthetic production in a Japanese larch stand. I Seasonal and vertical changes of leaf characteristics a long the light gradient in a canopy, Ecological Res. 7 (1992) 255-265.

[61] Lavigne M.B., Groth and net assimilation rates in thinned and thinned stands of balsam fir, Can. J. For. Res. 18 (1988) 1205-1212.

[62] Lee R., Forest microclimatology, Columbia University Press New York, 1978 p. 276.

[63] Levy G., Frochot H., Becker M., Installation des peuplements de chêne et facteurs du milieu, R.F.F. XLII 2 (1990) 240-245.

[64] Liechty H.O., Holmes M.J., Reed D.D., Mroz G.D., Changes in microclimate after stand conversion in two northern hardwoods stands, For. Ecol. Manag. 50 (1992) 253-264.

[65] Logan K.T., Growth of tree seedlings as affected by light intensity. I White birch, Yellow birch, sugar maple and silver maple, Department of forestry Publications $n^{\circ} 1121$, 1965, p. 16.

[66] Logan K.T., Growth of tree seedlings as affected by light intensity. II Red pine, White pine, Jack pine and eastern larch, Department of forestry Publications n¹160, 1966, p. 19.

[67] Logan K.T., Growth of tree seedlings as affected by light intensity. III. Basswood and white elm, Department of forestry Publications n ${ }^{\circ} 1176,1966$, p. 15.

[68] Logan K.T., Growth of tree seedlings as affected by light intensity. V. White Ash, Beech, Hemlock and general conclusion, Department of forestry Publications n 1323 , 1973, p. 12.

[69] Loustau D., Cochard H., Utilisation d'une chambre de transpiration portable pour l'estimation de l'évapotranspiration d'un sous-bois de Pin maritime à Molinie (Molinia coerulea (L.) Moench.) Ann. Sci. for. 48, 1 (1991) 29-45.

[70] Luttschawager D., Rust S., Wulf M., Forkert J., Huttl R.F., Tree canopy and herb layer transpiration in three Scots pine stands with different stand structures, Ann. For. Sci. 56 (4) (1999) 265-274.

[71] Lyr H., Effect of the root temperature on growth parameter of various European tree species, Ann. Sci. for. 53 (1996) 317-323.

[72] Madsen P., Growth and survival of Fagus silvatica seedlings in relation to light intensity and soil water content, Scan. J. For. Res. 9 (1994) 316-332.

[73] Margolis H., Brand D.G., An ecophysiological basis for understanding plantation establishment, Can. J. For. Res. 20 (1990) 375-390.

[74] Mc Clurklin D.G., Soil moisture trends following thinning in shortleaf pine, Soil Sci. Soc. Am. Proc. 25, 2 (1961) 135-138.
[75] Morikawa Y., Hattori S., Kiyono Y., Transpiration of a 31 year old Chamaecyparis obtusa Endl. stand before and after thinning, Tree Physiol. 20 (1986) 105-114.

[76] Odin H., Meteorology in forest operations, in Symposium on Forest meteorology, W.M.O. Otawa, 1978, pp. 167-177.

[77] Oswald H., Aussenac G., Stabilité des peuplements et traitements sylvicoles sur sols hydromorphes Séminaire «Conditions et effets des excés d'eau en Agriculture » INRA, Paris, 1985, pp. 147-155.

[78] Petersen T.D., Newton M., Zedaker S.M., Influence of Ceanothus velutinus and associates forbs on the water stress and stemwood production od Douglas-Fir, For. Sci. 34 (1988) 333-343.

[79] Perttu K., Climatic zones regarding the cultivation of Picea abies L; in Sweden. II. Radiation cooling and frost risk, Research notes 36, Swedish University of Agricultural Sciences, 1981, p. 25.

[80] Pienne H., Effects of increasing spacing on carbon mineralization rates and temperature in a stand of young balsam fir, Can. J. For. Res. 8 (1978) 398-406.

[81] Pienne H., Van Cleve K., Weight loss of litter and cellulose bags in a thinned white spruce forest in interior Alaska, Can. J. For. Res. 8 (1978) 42-46.

[82] Planchais I., Pontailler J.Y., Aplication d'un modèle de pénétration de la lumière à une jeune plantation de hêtre à abri latéral, Ann. Sci. For. 54 (1997) 243-260.

[83] Planchais I., Pontailler J.Y., Validity of leaf areas and angles estimated in a beech forest from analysis of gap frequencies, using hemispherical photographs and a plant canopy analyser, Ann. For. Sci. 56(1) (1999) 1-10.

[84] Porte A., Bosc A., Champion I., Loustau D., Estimating the foliage area of Maritime pine (Pinus pinaster Ait.) branches and crowns with application to modelling the foliage area distribution in the crown, Ann. Sci. For. 57 (2000) 73-86.

[85] Pothier D. Margolis A., Analysis of growth and light interception of balsam fir and white birch saplins following precommercial thinning, Ann. Sci. For. 48 (1991) 126-132.

[86] Prescott C.E., Effects of clearcutting and alternative silvicultural systems on rates of decomposition and nitrogen mineralisation in a coastal montane coniferous forest, For. Ecol. Manag. 95 (1997) 253-260.

[87] Price D.T., Black T.A., Kelliher F.M., Effects of salal understory removal on photosynthesis rate and stomatal conductance of young douglad fir tree, Can. J. For. Res. 16 (1986) 90-97.

[88] Raynor G., Wind and temperature structure in a Coniferous Forest and a contiguous field, For. Sci. 17 (1971) 351-363.

[89] Reynolds P.E., Simpson J.A., Lautenschlager R.A., Bell F.W., Gordon A.M., Buckley D. A., Gresch A., Alternative conifer release treatments affect below and nearground microclimate, For. Chron. 73 (1997) 75-82.

[90] Ritchie G.A., Evidence for red:far red signaling and photomorphogenic growth response in Douglas-fir 
(Pseudotsuga menziesii) seedlings, Tree Physiol. 17 (1997) 161-168.

[91] Roberts J., Pymar C.F., Wallace J.S., Pitman R.M., Seasonal changes in leaf area, stomatal conductance and transpiration from bracken below a forest canopy, J. Appl. Ecol. 17 (1980) 409-422.

[92] Roussel L., Photologie forestière, Masson et Cie, Paris, 1972, p. 144.

[93] Sampson D.A., Smith F.W., Influence of canopy structure on light penetration in lodgepole pine (Pinus contorta var. latifolia) forests, Agri. For. Meteorol. 64 (1993) 63-79.

[94] Schnock G., Le bilan d'eau et ses principales composantes dans une chênaie mélangée calcicole de Haute Belgique (Bois de Virelles Blaimont), Thèse Université Libre de Bruxelles, 1970, p. 352.

[95] Schulze E.D., Der $\mathrm{CO}_{2}$ Gaswechsel der Buche (Fagus silvatica L.) in Abhangigkeit von den Klimafaktoren im Freiland, Flora 159 (1970) 177-232.

[96] Seltzer P., Études microclimatologiques en Alsace, Thèse de Doctorat es Sciences, Université de Strasbourg, 1935, p. 57.

[97] Sprugel D.G., Brooks J.R., Hinckley T.M., Effects of light on shoot geometry and needle morhology in Abies amabilis Tree Physiol. 16 (1996) 91-98.

[98] Stoeckeler J.H., Spring frost damage in young forests plantings near La Crosse, Wisconsin, Journ. Forestry 63 (1965) $12-14$.

[99] Stogsdill W.R., Witter R.F., Hennessey T.C., Dougherty P.M., Water use in thinned Loblolly Pine plantations, For. Ecol. Manag. 50, 3-4 (1992) 233-245.

[100] Sucoff E., Hong S.G., Effects of thinning on needle water potential in Red Pine, For. Sci. 20 (1974) 25-29.

[101] Tranquillini W., Physiological ecology of the alpine timberline, 1979, Springer Berlin.
[102] Wang J.R., Simard S.W., Kimmins J.P., Physiological responses to paper birch to thinning in British Columbia, For. Ecol. Manag. 73 (1995) 177-184.

[103] Yasushi Morikawa, Shigeaki Hattori, Yoshiyuki Kiyono, Transpiration of a 31 year old Chamaecyparis obtusa Endl. stand before and after thinning, Ree Physiology 2 (1986) 105-114.

[104] Zahner R., Water deficits and growth of trees in "Water deficits and plant growth." II, Kozlowski editor, Academic Press, New York, 1968, pp. 199-254.

[105] Ziegenhagen B., Kausch W., Productivity of young shaded oaks (Quercus robur L.) as corresponding to shoot morphology and leaf anatomy, For. Ecol. Manag. 72 (1995) 97108.

[106] Van Hees A.F.M., Growth and morphologie of pedunculate oak (Quercus pedunculata) and beech (Fagus silvatica) seedlings in relation to shading and drought, Ann. Sci. For. 54 (1997) 9-18.

[107] Whitehead D., Kelliher F.M., Lane P., Pollock D., Seasonal partitioning of evaporation between trees and understorey in a widely spaced Pinus radiata stand, J. Appl. Ecol. 31 (1994) 528-542.

[108] Whitehead D., Kelliher F.M., A canopy water balance model for a Pinus radiata stand before and after thinning, Agri. For. Meteorol. 55, 1-2 (1991) 109-126.

[109] Woodman J.N., Variation of net photosynthesis within the crown of a large forest-crown conifer. Photosynthetica 5 (1971) 50-54.

[110] Wulf M., Luttschwager D., Forkert J., und Huttl R., Untersuchungen zum deckungs-und Transpirationsgrad augewalhlter Pflanzenarten der Krautschicht in Kiefernbestanden, Agew. Bot. 70 (1996) 165-171. 